\title{
Determination Factor Alumni and Student of Economic Faculty Lamongan Islamic University to Become Enterpreneur
}

\author{
Nanto Purnomo * Abid Muhtarom** \\ * Magister Management Studies of Madura Trunojoyo University, purnamananto21@gmail.com, Surabaya, Indonesia \\ ** Doctoral Degree Studies the science of the economy of Airlangga University, abid@chelseafc.or.id, Surabaya, Indonesia
}

\section{ARTICLE INFO}

\section{Article history:}

Received 14 Februari 2018

Received I Revised 24 Juli

2018

Accepted 29 Juli 2018

Keywords:

Motivation risk

tolerance, freedom in

working, success

themselves \& the

decision

entrepreneurs 
The current condition of the world of work becomes more difficult while the community that need the work continues to increase. One way to solve the current conditions such as with we make the work not seeking work namely entrepreneurs. According to the data from the BPS the level of entrepreneurship in Indonesia have increased in the year 2013/2014 and still 1.67 percent now, based on data BPS already rose to 3.1 percent .

Gilad dan Levini (1986) proposed two of the theory that is closely related to the motivation to become an entrepreneur. The theory of "push" and the theory of "attraction". The theory explained that people motivation is estabilised from internal factor (push) and external factor (attraction).

According from previous researcher conducted by Adi first (2010) where conducted on Collage Student Economy Diponegoro University find that interest entrepreneurs as risk tolerance, success themselves and the freedom in working have significant effect of interest entrepreneurs both partially and simultaneously. Srimulyani (2014) on Collage student of Manajemen Unika Widya Mandala Madiun, find that factors motivate to become entrepreneurs are the desire feel free work, self-success in achieve, and tolerance of risk. There are still few research studying about determinant factor that influence collage student to become enterpreneur, so there are still further research to generalize the result from preveous research and find the fix factor that influence decision to become enterpreneur.

The purpose of this research is to find the determinant factor to become enterpreneur which developed from Gilad and Levine theory push and attraction (1986). There are three factor suspected to become determinant factor, there are; the desire to feel free work, self success in achive and tolerance of risk. This research is further research from previous research who conducted by Adi First (2010) and Srimulyani (2014) which generalized the result from another subject as the differences from previous research. This research use collage student Faculty of Economics Islamic University Lamongan as the subject research. Faculty of Economics University of Islam Lamongan has a vision to develop knowledge-based economy small medium businesses and financial to produce graduates who are able to work professional and soulful Islamic law as well as the response to the economic development.

From the description of the researcher conducted research on entrepreneurship at the Faculty of Economics of Islamic University of Lamongan, this is because the college is a very strategic educational institution in its role to develop mental attitude, motivation and knowledge of entrepreneurship students. Through college entrepreneurship courses have hope and purpose so that its graduates are not confused and clumsily plunge into society

\section{METHOD}

The type of this study were quantitative descriptive, namely the research in a simple way to explain the phenomenon that is using numbers to classify individuals or groups (Suharsaputra, 2012: 42). In this case the author want to get a clearer picture about the risk tolerance factor analysis, freedom in the work and success of himself against the decision entrepreneurs ( case study on the alumni \& students Economic Faculty, Lamongan Islamic University).

The determination of the sampling techniques used in this research is simple random sampling, where this research in the taking of the members of the sample from the population of random without regardless of who is in the population (Sugiyono, 2014: 118). The number of sample itself in specify 
using the formula property Slovin. According to Slovin in Suharsaputra (2012: 119) presents a formula for the determination of the great samples are as follows :

$$
\mathrm{N}=\mathrm{N} /\left(1+\mathrm{Ne}^{2}\right)
$$

$\mathrm{N}=$ number of samples

$\mathrm{N}=$ The number of the population

E 2 = fault tolerance that will be taken by Researchers $(10 \%$ or 0.1$)$

Where this research uses the population 2359 people so the number of samples in specify in this research is :

$\mathrm{N}=93,74$ in round become 94 people.

The technique of data collection using the technique of questionnaires / questioner, interview/ interview, observations. The source of the data in this research using primary and secondary data. In this research primary data obtained by giving questionnaires (questioner) which includes questionnaires about tolerance to risk, freedom in the work and success of himself against the decision of the entrepreneurs that given to students / alumni Economic Faculty, Lamongan Islamic University which have the decision entrepreneurs who acted as the sample. Secondary data is done through the study of the library includes articles from newspapers, magazines / internet, books, the scientific journal , and bachelor theses.

In this research independent variables include :

\section{Risk tolerance (X1)}

The indicators include : Collective, Like challenges, commitment, patience and understanding risk

2. The freedom in the work (X2)

The indicators include : No delight in set, personal freedom / independent, Hard head is intuition and likes to take the initiative

3. The success of themselves (X3)

The indicators include : Optimistic Spirit in work, the orientation of the destination,Competent, diligent and resilient

In this research dependent variables is :

1. The decision entrepreneurs (Y)

The indicators include : self confidence, innovative and creative, leadership, oriented on the future and the existence of pleasure.

The analysis use in this research are validity and reliability test to check the quesioner And multiple regression anaysis (Determination test and $\mathrm{T}$ test) to find the determinant factor to become enterpreneur. 


\section{RESULTS AND DISCUSSION}

\subsection{Validity and Reliability Test}

Table 1

Validity Test

\begin{tabular}{lcccc}
\hline \multicolumn{1}{c}{ Variables } & Indicator & Accumulated r & r Table & Conclusion \\
\hline Risk Tolerance & X1.1 & 0,651 & 0,203 & Valid \\
& X1.2 & 0,633 & 0,203 & Valid \\
& X1.3 & 0,716 & 0,203 & Valid \\
Freedom in Work & X1.4 & 0,626 & 0,203 & Valid \\
& X1.5 & 0,663 & 0,203 & Valid \\
X2.1 & 0,736 & 0,203 & Valid \\
The Succes of Themself & X2.2 & 0,610 & 0,203 & Valid \\
& X2.3 & 0,587 & 0,203 & Valid \\
& X2.4 & 0,660 & 0,203 & Valid \\
& X2.5 & 0,565 & 0,203 & Valid \\
X3.1 & 0,713 & 0,203 & Valid \\
Decision Became Enterpreneur & X3.2 & 0,729 & 0,203 & Valid \\
& X3.3 & 0,646 & 0,203 & Valid \\
& X3.4 & 0,777 & 0,203 & Valid \\
& X3.5 & 0,622 & 0,203 & Valid \\
& Y.1 & 0,643 & 0,203 & Valid \\
& Y.2 & 0,684 & 0,203 & Valid \\
& Y.3 & 0,646 & 0,203 & Valid \\
& Y.4 & 0,650 & 0,203 & Valid \\
\hline
\end{tabular}

From the validity test results on table 1 above. The result obtained a value for a variable X1 (Risk tolerance) is the value of X 1.1 USD 0,651 , value X 1.2 USD 0,633, value X 1.3 0,716, value X 1.4 USD 0,626 , and the value of $X 1.5$ of 0,663 . For the variables $X 2$ (freedom in the Work ) is the value of $X$ 2.1 USD 0,736, value X 2.2 USD 0,610, value X 2.3 USD 0,587, value X 2.4 USD 0,660, and the value of X 2.5 0,565. For the variables X3 ( Success themselves ) is the value of X 3.1 USD 0,713, value X 3.2 USD 0,729 , value $X 3.3$ USD 0,646 , value $X 3.4$ USD 0,777 , and the value of $X 3.5$ of 0,622 . For the variables Y (Decision Entrepreneurs) is the value of Y 1.1 USD 0,623, value Y 1.2 USD 0,684, value Y 1.3 USD 0,646, value Y 1.4 USD 0,650, and the value of the Y 1.5 of 0,649.

Thus it can be concluded that the indicator variables Risk tolerance (X1), the freedom in the Work (X2), Success themselves (X3) and decisions Entrepreneurs (Y) stated valid because the value of $r$ count consecutive patients $r$ table of 0,203 . So that all the existing indicator on the variables - research variable is worthy to be used.

Table 2

Reliability Test

\begin{tabular}{lccc}
\hline \multicolumn{1}{c}{ Variables } & Cronbach Alpha & St. Reliabelity & Conclusion \\
\hline Risk Tolerance & 0,662 & 0,60 & reliabel \\
Freedom in Work & 0,626 & 0,60 & reliabel \\
The Succes of Themself & 0,662 & 0,60 & reliabel \\
Decision Became Enterpreneur & 0,734 & 0,60 & reliabel \\
\hline
\end{tabular}


From the reliability test results on table 2 above, each variables obtained the value of Cronbach Alpha namely to risk tolerance variables (X1) of 0,662, freedom in working (X2) of 0,626, Success themselves (X3) of 0,734 and decisions Entrepreneurs (Y) of 0,655.so it can be concluded that all variables said reliable because it has the value of Cronbach Alpha consecutive patients 0.6. So that all the variables are on the research variable indicator is allegedly worthy to be used.

\section{Multiple Regression Analysis}

\section{Koefesien Determination Test}

Table 3

Koefesien Determination Test

\begin{tabular}{lllll}
\hline Model & R & R Square & Adjusted R Square & Std. Error \\
\hline & 0,705 & 0,497 & 0,480 & 1,63605
\end{tabular}

From table 3 above the result show that the coefficient determination (R Square) is 0,497 . This means that the $49.7 \%$ decision entrepreneurs can be explained by the variables from the three independent variables the risk tolerance, freedom in the work and success of themselves. While the rest of $50.3 \%$ can be explained by other reasons outside the model.

\section{Partial Test $(\mathrm{T}-$ test $)$}

Tabel 4

Partial Test (T - test)

\begin{tabular}{lllll}
\hline Variables & Std Coeficient & $\mathrm{t}$ value & Sig & Conclusion \\
\hline Constant & & 2,203 & 0,030 & \\
$\mathrm{X} 1$ & 0,267 & 2,624 & 0,010 & Significant \\
$\mathrm{X} 2$ & 0,272 & 3,083 & 0,003 & Significant \\
$\mathrm{X} 3$ & 0,330 & 3,569 & 0,001 & Significant \\
\hline
\end{tabular}

From the result of partial showed in table 4 above we can make equation as follows :

$$
\mathrm{Y}=3,790+0,267 \mathrm{X} 1+0,272 \mathrm{X} 2+0,330 \mathrm{X} 3
$$

From the equation 2 can be explained that :

$\mathrm{A}=3,790$ is planck which means that when the free variable in research (risk tolerance factors, freedom in the work and the success of themselves ) influence $=0$, then the level of decisions entrepreneurs rose by 3,790 .

$\mathrm{B}_{1}=0,267$, means when the factor risk tolerance propagated up 1 units then the level of the decision of the entrepreneurs will rise or rise by 0,267 with assumption of other variables that affect considered constant $\left(\mathrm{a}, \mathrm{x}_{2}\right.$ and $\left.\mathrm{x}_{3}=0\right)$. 
$\mathrm{B}_{2}=0,272$, when the factor of freedom in working propagated up 1 units then the level of the decision of the entrepreneurs will rise or rise by 0,272 with assumption of other variables that affect considered constant $\left(\mathrm{a}, \mathrm{x}_{1}\right.$, and $\left.\mathrm{x}_{3}=0\right)$.

$\mathrm{B}_{3}=0,330$, means when success factors themselves propagated up 1 units then the level of the decision of the entrepreneurs will rise or rise by 0,330 with assumption of other variables that affect considered constant ( $\mathrm{a}, \mathrm{x}_{1}$ and $\left.\mathrm{x}_{2}=0\right)$ ).

From the results of the independent variables above can be seen that the whole independent variable has a positive direction. This means that has the direction of the changes in the direction of the bound variable is increased risk tolerance, freedom in the work and the success of the self will improve

the decision entrepreneurs. And from the equation can be seen that the most dominant factor in encouraging the decision entrepreneurs are success factors themselves with the regression coefficient of 0,330. From the result in table 4 above, it showed that each independent variabel have signaificant value ( $\mathrm{p}$ - value ) under 0,05 , from this result we can concluded that every independent variable (risk tolerance, freedom in work, success for themself) have significant influence to decision to become enterpreneurship.

\section{CONCLUSION}

From the result and discusion before, we can take conclusion that risk tolerance, freedom in the work and success themeself are become determinant of student of Economic Faculty of Lamongan Islamic University to become enterpreneurship. High risk high return maindset is become the fundamental thinking of enterpreneurship is become one of motive to become enterpreneur because student in Economic Faculty of Lamongan Islamic University are risk taker who happy with the risk and no fear with the risk. Freedom in sets of time and rules is the reason why people choose become enterpreneur that freedom in the work is a good freedom sets time, free from supervise and free of the rules of the game is pressing/ interventions, free from the rules of the culture of the organization / company that is the motivation of the person in the entrepreneurs. The success of himself is one of the representatives from the motivation to become entrepreneurs, they believed that the entrepreneur has a greater potential for success than on the work for other people to get a more valuable

\section{REFERENCES}

Adi First, Angki. 2010. The analysis that Infuenced motivate college students wanting to become entrepreneurs (study on the student S1 Economics Faculty of Diponegoro Semarang) . [Bachelor Theses], Diponegoro University Semarang.

Alma, Buchari. 2010. Entrepreneurship. Alfabeta, Bandung

Arikunto, Suharsimi. 2010. Research procedure a practical approaches. Revised edition. Copyright Rineka. Jakarta

Fahmi, Irham. 2011. The management of decision-making . Alfabeta. Bandung 
Gilad, B., \& Levini, P. (1986). A Behavioral Model Of Entrepreneurial Supply. Journal of Small Business Management, Vol. 24.

Hasibuan, Malayu Sutan Parlagutan. 2014. The Management : basis, understanding and the problem. Revised edition. The earth characters. Jakarta.

Hendro. 2011. Entrepreneurial Dasar-Dasar Guidelines for students to know, understand and enter the world of business. Erlangga Publisher. Jakarta

Cashmere feel . 2013. Entrepreneurship. The eagle release. Jakarta

Saiman, Leonardus. 2012. Entrepreneurship (theory, practice, and cases - the case). Salemba four. Jakarta.

Silalahi, Ulber. 2012. Social Research Methods. Refika Aditama. Bandung.

Siswandi. 2011. Company Management application: case analysis and problem solving . The third edition. Media Discourse partners. Jakarta.

Srimulyani, V. A. (2014). Kajian Kajian Faktor Faktor Motivasi yang Berpengaruh Terhadap Minat Berwirausaha pada Mahasiswa Program Studi Manajemen Fakultas Ekonomi Unika Widya Mandala Madiun. Widya Warta, 1 - 15.

Sugiyono. 2014. Research Method Business . Alfabeta. Bandung

Suharsaputra, Uhar. 2012. Research Method . PT Refika Aditama. Bandung.

Sunyoto, Danang. 2013. The theory of the questionnaire and Data Analysis. For Marketing and consumer behavior. Graha Knowledge. Yogyakarta.

Suryana. 2014. Entrepreneurship Tips and the process to success . The Edition 4. Salemba Four, Jakarta Sutrisno, Edy. 2011. Human Resources Management .Kencana Prenada Media Group. Jakarta Torang, Syamsir. 2013. The organization and management ( behavior, the structure, culture and organizational change).CV Alfabeta. Bandung 